\title{
Morphometric Analysis of the Gal Oya River Basin Using Spatial Data Derived from GIS
}

\author{
N.S. Withanage, N.D.K. Dayawansa ${ }^{1 *}$ and R.P. De Silva ${ }^{1}$ \\ Postgraduate Institute of Agriculture \\ University of Peradeniya \\ Sri Lanka
}

\begin{abstract}
Basin morphometry is a means of mathematically quantifying different aspects of a drainage basin. In the present study, morphometric analysis of the Gal Oya river basin was done to elucidate information on the morphometry of the Gal Oya river basin and to assess its hydrological characteristics and flood potentials based on the morphological characteristics. The study was carried out using spatial data obtained from Geographical Information Systems (GIS). The morphometric parameters considered for the analysis include the linear, areal and relief aspects of the basin. Morphometric analysis of the river network and the basin revealed that the Gal Oya basin has $6^{\text {th }}$ order river network (as per the Strahler's classification) with a dendritic drainage pattern and moderate drainage texture. The obtained values of bifurcation ratio, drainage density, circularity ratio, elongation ratio, form factor, stream frequency and drainage intensity indicate that the basin produces a flatter peak of direct runoff for a longer duration and such flood flows emerging from elongated basins are easier to manage than those from circular basins.
\end{abstract}

Keywords: Flood characteristics, Gal Oya river basin, Geographical Information Systems, morphometric analysis, spatial data

\section{INTRODUCTION}

Morphometry is defined as the measurement and mathematical analysis of the configuration of the earth's surface and of the shape and dimension of its landforms (Clarke, 1966). Morphometric methods, though simple, have been applied for the analysis of area-height relationships, determination of erosion surfaces, slopes, relative relief and terrain characteristics, river basin evaluation, watershed prioritization for soil and water conservation activities in river basins (Kanth, 2012). The morphometric analyses of different basins have been done by various scientists using conventional methods (Horton, 1945; Smith, 1950; Strahler, 1957) and earth observation data and GIS methods (Narendra and Rao, 2006). The use of GIS technique in morphometric analysis has emerged as a powerful tool in recent years particularly for remote areas with limited access.

The morphometry of the river basins relates to the hydrological and geomorphic response of processes like runoff, soil erosion, floods and droughts, river sedimentation, changing river flows and branching habit of the streams, flow characteristics of the drainage lines, and on the performance and sustainability of the associated dams and reservoirs if available within the basin (Garde, 2005; Mohd et al., 2013). According to Strahler (1964), systematic

1 Department of Agricultural Engineering, University of Peradeniya, Sri Lanka.

* Corresponding author: dammid@pdn.ac.lk 
description of the geometry of a river basin and its stream channel requires measurement of linear aspects of the drainage network, areal aspects of the drainage basin, and relief (gradient) aspects of the channel network and contributing ground slopes. As linear aspects, stream order, stream length, stream number, and bifurcation ratios are considered. Areal aspects are basin area, basin perimeter, length of overland flow, drainage density, stream frequency, drainage intensity, circularity ratio, elongation ratio and form factor. The basin relief, relief ratio and relative relief are commonly evaluating relief aspects (Horton, 1945; Melton, 1957; Miller, 1953; Schumm, 1956; Strahler, 1964).

There are relationships between river basin morphometric parameters and flood potential. For instance, it has been discovered that the higher the drainage density, the faster the runoff and the more significant the degree of channel abrasion for a given quantity of rainfall (Pidwirny, 2006). Further, the author has stated that the measurement of drainage density provides hydrologists and geomorphologists with a useful numerical measure of landscape dissection and runoff potential. In homogeneous bedrock, bifurcation ratio influences the landscape morphometry and plays an important control over the "peak" of the runoff hydrograph (Chorley et al., 1957). Waugh (1996) noted that the human significance of the bifurcation ratio is that, as the ratio is reduced the risk of flooding within the basin increases. Strahler (1964) noted that the shape of a drainage basin may conceivably affect stream discharge characteristics. Long narrow basins with high bifurcations would be expected to have attenuated flood discharge periods, whereas round basins of low bifurcation ratio would be expected to have sharply peaked flood discharges. Quantitative expression of drainage basin shape or outline form was made by Horton (1932) through a form factor. Schumm (1956) used the elongation ratio and Miller (1953) proposed the circularity ratio to describe basin shape.

Annual flooding is a common menace of the lower parts of Gal Oya river basin. Hence, this study was carried out to elucidate information on the morphometry of the Gal Oya river basin and to assess its hydrological characteristics and flood potentials based on the morphological characteristics.

\section{Study area}

The Gal Oya is a river draining through eastern Sri Lanka and the river basin covers an area of $1873 \mathrm{~km}^{2}$. This is the $44^{\text {th }}$ basin among the named 103 major river basins in Sri Lanka. The length of the Gal Oya river is about $108 \mathrm{~km}$ and it is the $16^{\text {th }}$ longest river in Sri Lanka. It rises in the hill country east of Badulla, flows towards the east coast of Sri Lanka and joins to the Indian Ocean $16 \mathrm{~km}$ south of Kalmunai (Fig. 1). The Gal Oya river is the main source feeding the Gal Oya scheme, a government programme that dammed the Gal Oya at Bintenne and other smaller rivers to create Senanayake Samudra, which is the largest tank (reservoir) in Sri Lanka. Namal Oya Reservoir, Jayanthi Wewa and Irakkamam Wewa are the other main water tanks in this basin. The Gal Oya basin also bears the Gal Oya National Park, Gal Oya valley Northeast (Ampara) Santuary and Gal Oya valley Southeast (Sellaka Oya) Santuary giving habitats to wide variety of wildlife, especially for some endangered species of birds and mammals (National Atlas of Sri Lanka, 2007).

The average rainfall over the basin is $2032 \mathrm{~mm}$ and the discharge volume to the sea is 237 MCM leading to a runoff/rainfall ratio of 7\% (National Atlas of Sri Lanka, 2007). The basin falls under different Agro-Ecological Zones, viz $\mathrm{IU}_{2}, \mathrm{IU}_{3 \mathrm{c}}, \mathrm{IM}_{1 \mathrm{a}}, \mathrm{IM}_{2 \mathrm{~b}}, \mathrm{IM}_{2 \mathrm{c}}, \mathrm{IL}_{1 \mathrm{c}}, \mathrm{IL}_{2}, \mathrm{DL}_{2 \mathrm{a}}$ and $\mathrm{DL}_{2 \mathrm{~b}}$. The geology of the basin area falls under the Highland Complex and Eastern Vijayan Complex (Madduma Bandara, 2000). 


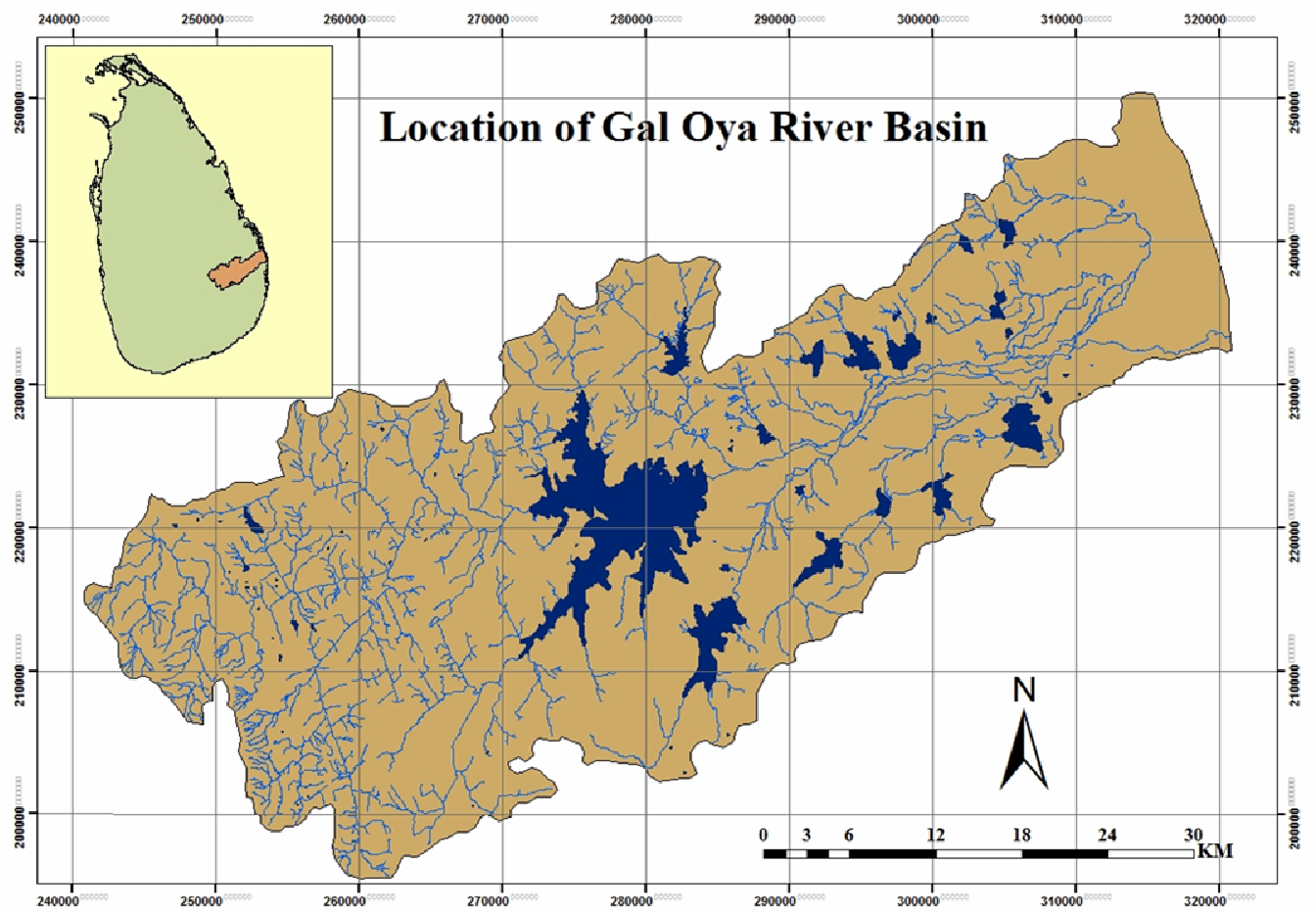

Fig 1. Gal Oya river basin in Sri Lanka

\section{MATERIALS AND METHODS}

The Gal Oya river basin boundary was digitized based on the river basins boundary map published by the Department of Agrarian Services, Sri Lanka (2012) and it was verified with the help of contour maps published by the Survey Department of Sri Lanka (2007). The digital layers of the hydrological network, land use pattern and geological conditions of the river basin were obtained by digitizing 1:50,000 toposheets: Padiyatalawa (56), AmparaKalmunai (57-58), Bibile (63), Thirrukkovil-Thampaddi (64-65) and Monaragala (70) published by the Survey Department of Sri Lanka in 2007. The ArcGIS-9.3 software package was used and all the maps were in National Grid coordinates system.

Linear, areal and relief aspects of morphometric parameters, viz stream order (U), number of streams in each order $(\mathrm{Nu})$, stream length $(\mathrm{Lu})$, mean stream length (Lsm), stream length ratio $(\mathrm{RL})$, bifurcation ratio $(\mathrm{Rb})$ mean bifurcation ratio $(\mathrm{Rbm})$, drainage density $(\mathrm{Dd})$, stream frequency (Fs), form factor (Rf), circulatory ratio $(\mathrm{Rc})$, elongation ratio $(\mathrm{Re})$, drainage texture (T), drainage intensity (Id), length of overland flow (Lo), basin relief $(\mathrm{H})$, relief ratio $(\mathrm{Rh})$ and relative relief (Rhp) were computed using GIS Software analysis tools and different models developed and published through the scientific literature in Geomorphology (Table 1).

Rainfall data at Bibile and Padiyathalawa gauging stations obtained from the Meteorological Department of Sri Lanka and the flood records at Ampara District obtained from the website of Disaster Management Centre of Sri Lanka were further used to augment the information 
resulted from the morphometric analysis of the basin to assess the hydrological characteristics and flood potentials of the Gal Oya river basin.

Table 1. Methods used for the morphometric analysis

\begin{tabular}{|c|c|c|}
\hline Morphometric Parameter & Method & Reference \\
\hline \multicolumn{3}{|l|}{ Linear Aspects } \\
\hline Stream order $(\mathrm{U})$ & Hierarchical rank & Strahler (1964) \\
\hline Number of Streams $(\mathrm{Nu})$ & $\mathrm{Nu}=\mathrm{N} 1+\mathrm{N} 2 \ldots+\mathrm{N} 6$ & Horton (1945) \\
\hline Stream length in $\mathrm{km}(\mathrm{Lu})$ & $\mathrm{Lu}=\mathrm{L} 1+\mathrm{L} 2 \ldots+\mathrm{L} 6$ & Horton (1945) \\
\hline Mean stream Length (Lum) & $\mathrm{Lum}=\mathrm{Lu} / \mathrm{Nu}$ & Strahler (1964) \\
\hline Bifurcation Ratio (Rb) & $\mathrm{Rb}=\mathrm{Nu} / \mathrm{Nu}+1$ & Schumm (1956) \\
\hline Stream length Ratio (RL) & $\mathrm{RL}=\mathrm{Lu} / \mathrm{Lu}-1$ & Horton (1945) \\
\hline \multicolumn{3}{|l|}{ Areal Aspects } \\
\hline Area in $\mathrm{km}^{2}(\mathrm{~A})$ & Area calculation & Schumm (1956) \\
\hline Perimeter in km $(\mathrm{P})$ & Perimeter calculation & Schumm (1956) \\
\hline Length of the basin in $\mathrm{km}(\mathrm{Lb})$ & Length calculation & Schumm (1956) \\
\hline Drainage density (Dd) & $\mathrm{Dd}=\mathrm{Lu} / \mathrm{A}$ & Horton (1932) \\
\hline Stream frequency (Fs) & $\mathrm{Fs}=\mathrm{Nu} / \mathrm{A}$ & Horton (1932) \\
\hline Circulatory ratio (Rc) & $\mathrm{Rc}=12.57 *\left(\mathrm{~A} / \mathrm{P}^{2}\right)$ & Miller (1953) \\
\hline Elongation ratio $(\mathrm{Re})$ & $\mathrm{Re}=2 / \mathrm{Lb} * \sqrt{ }(\mathrm{A} / \pi)$ & Schumm (1956) \\
\hline Form factor $(\mathrm{Ff})$ & $\mathrm{Ff}=\mathrm{A} / \mathrm{Lb}^{2}$ & Horton (1932) \\
\hline Drainage texture $(\mathrm{T})$ & $\mathrm{T}=\mathrm{Nu} / \mathrm{P}$ & Horton (1945) \\
\hline Drainage intensity (Id) & $\mathrm{Id}=\mathrm{Fs} / \mathrm{Dd}$ & Faniran (1968) \\
\hline Length of overland flow (Lo) & $\mathrm{Lo}=1 / \mathrm{Dd} * 0.5$ & Horton (1945) \\
\hline \multicolumn{3}{|l|}{ Relief Aspects } \\
\hline Basin relief in $\mathrm{m}(\mathrm{H})$ & $\mathrm{H}=\mathrm{Z}-\mathrm{z}$ & Strahler (1957) \\
\hline Relief ratio $(\mathrm{Rh})$ & $\mathrm{Rh}=\mathrm{H} / \mathrm{Lb}$ & Schumm (1956) \\
\hline Relative Relief (Rhp) & $\mathrm{Rhp}=\mathrm{H}^{*} 100 / \mathrm{P}$ & Melton(1957) \\
\hline
\end{tabular}




\section{RESULTS AND DISCUSSION}

The analyzed drainage network of the Gal Oya river basin is presented in Fig. 2. The linear aspects of the morphometric analysis conducted for the river network are given in Table 2.

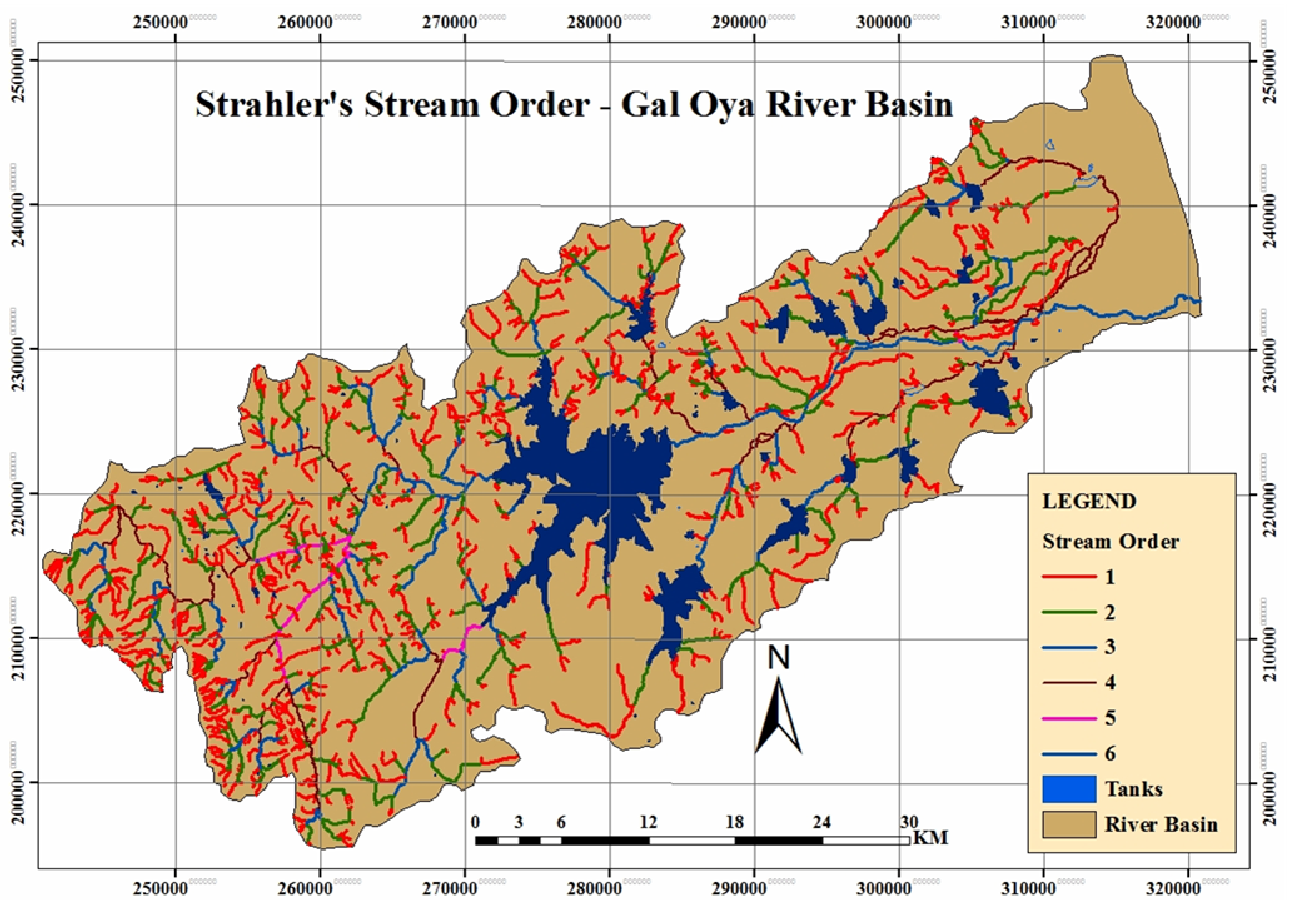

Fig 2. Strahler's stream orders of Gal Oya river basin

\section{Linear aspects}

The stream links and the nodes (confluences) characterize 'Linear aspects' of the basin. Table 2 shows the results of the linear aspects of morphometric parameters of the Gal Oya river basin.

The designation of stream order is the first step in morphometric analysis of a drainage basin and it is defined as a measure of the position of a stream in the hierarchy of tributaries (Strahler, 1964). A total number of 1396 streams found in the studied basin are linked up to the $6^{\text {th }}$ order, spreading over an area of $1873 \mathrm{~km}^{2}$ (Fig. 2).

Table 2 shows, both total lengths of streams and total numbers of streams in each order are decreasing with increasing order as explained by Horton (1945) and increasing mean stream length with increasing order as explained by Strahler (1964). Stream length is one of the significant features of the basin, as it reveals surface runoff characteristics. Streams of relatively smaller lengths indicate that, the area is with high slopes. Longer lengths are indicative of flatter gradient. Usually, the total length of stream segments is highest in first order streams, and it decreases as the stream order increases and this basin also shows a similar pattern (Fig. 3). The Lum is a characteristic property related to the drainage network components and its associated basin surfaces (Strahler, 1964). The results show that Lum is increasing from 0.79 to 77.54 (Table 2). 
Table 2. Linear aspects of the river basin

\begin{tabular}{lccccc}
\hline $\begin{array}{l}\text { Stream } \\
\text { Order } \\
(\mathbf{U})\end{array}$ & $\begin{array}{c}\text { Number of } \\
\text { Streams in } \\
\text { each order } \\
(\mathbf{N u})\end{array}$ & $\begin{array}{c}\text { Total Stream } \\
\text { Length in km } \\
(\mathbf{L u})\end{array}$ & $\begin{array}{c}\text { Mean Stream } \\
\text { Length in km } \\
(\mathbf{L u m})\end{array}$ & $\begin{array}{c}\text { Bifurcation } \\
\text { Ratio (Rb) }\end{array}$ & $\begin{array}{c}\text { Stream } \\
\text { Length } \\
\text { Ratio (RL) }\end{array}$ \\
\hline 1 & 992 & 780.76 & 0.79 & - & 0.58 \\
2 & 327 & 451.19 & 1.38 & 3.03 & 0.63 \\
3 & 57 & 283.82 & 4.98 & 5.74 & 0.64 \\
4 & 15 & 181.45 & 12.10 & 3.80 & 0.59 \\
5 & 4 & 107.15 & 26.79 & 3.75 & 0.72 \\
6 & 1 & 77.54 & 77.54 & 4.00 & 0.72 \\
\hline Total & 1396 & 1881.91 & - & - & - \\
\hline
\end{tabular}

A dendritic drainage pattern can be identified in the basin and it is probably the most common drainage pattern identified in Sri Lankan river basins as well as in the world. This is characterized by irregular branching of tributary streams in many directions and at almost any angle usually less than $90^{\circ}$. Dendritic patterns develop on rocks of uniform resistance and indicate a complete lack of structural control. This pattern is more likely to be found on nearly horizontal sedimentary rocks or on areas of massive igneous rocks. They may also be seen on complex metamorphosed rocks (Garde, 2005). According to Cooray (1984) the basin belongs to the Vijayan Complex and it also has meta-sedimentary and meta-igneous rocks.

Horton (1945) considered bifurcation ratio as an index of reliefs and dissections. The $\mathrm{Rb}$ values can be obtained by dividing the number of streams in one order by the number in the next higher order (Schumm, 1956). The $\mathrm{Rb}$ is a dimensionless property and generally ranges from 3.0 to 5.0 (Strahler 1957). The values obtained for the study area range from 3.03 to 5.74 (Table 2). According to Strahler (1957), Rb can also be computed by plotting the stream order versus logarithm of the stream number and the average $\mathrm{Rb}$ can be computed by determining anti-logarithm of the slope. The calculated average $\mathrm{Rb}$ using the above approach for the basin is 4.07. Strahler (1957) demonstrated that Rb shows a small range of variation for different regions or for different environments except where the powerful geological controls dominate. It has been observed that $\mathrm{Rb}$ is not same from one order to the next order and these irregularities are dependent upon the geological and lithological development of the drainage basin (Strahler, 1964). The lower values of $\mathrm{Rb}$ are characteristics of the watersheds, which have suffered less structural disturbances (Strahler, 1964; Nag, 1998). In the present study, a higher $\mathrm{Rb}$ value of the basin indicates strong structural disturbances have occurred in the basin when the underlying geological structure transforming from one series to another series. Cooray (1984) provides evidences for the occurrence of transitional zone in the eastern boundary between the Vijayan series and Highland series. Further, Chorley et al. (1957) has noted that the lower the bifurcation ratio, the higher the risk of flooding, particularly of parts and not the entire basin. The higher $\mathrm{Rb}$ values of all orders (3.03-5.74) and the higher average $\mathrm{Rb}$ value (4.07) together with the elongated shape of the studied basin would result a lower and extended peak flow, which will reduce the risk of flooding within the basin. 


\section{Areal aspects}

Area of a basin (A) and perimeter (P) are important parameters in quantitative geomorphology. The area of the basin is defined as the total area projected upon a horizontal plane. Perimeter is the length of the boundary of the basin. It is measured along the divide between watersheds and may be used as an indicator of watershed size and shape. The area and the perimeter of the Gal Oya river basin are $1873 \mathrm{~km}^{2}$ and $284 \mathrm{~km}$, respectively.

The length of the basin ( $\mathrm{Lb}$ ) has been defined in different ways by many scientists. Horton (1932) defined basin length as the straight-line distance from a basin mouth to the point on the water divide intersected by the projection of the direction of the line through the source of the main stream. Schumm (1956) defined it as the longest dimension of the basin parallel to the principal drainage line. The length of the Gal Oya river basin was calculated in accordance with the definition of Schumm (1956) and found as $80.88 \mathrm{~km}$.

The Fs introduced by Horton (1932) is the total number of stream segments of all orders per unit area as an indicative of stream network distribution over the river basin. Kale and Guptha (2001) have found that the Fs value may range from less than 1 to 6 or even more depending on the lithology of the basin. In the present study, the stream frequency of the basin is 0.75 and it indicates a low value. This reveals that the basin possesses a low relief and almost a flat topography (Horton, 1932).

Miller (1953) defined a dimensionless Rc as the ratio of basin area to the area of a circle having the same circumference as the perimeter of the basin. The author described that the circularity ratios range from 0.4 to 0.5 which indicates strongly elongated and permeable homogenous geologic materials. Higher the value of Rc, greater the circular shape of the basin and vice-versa. The Rc is mainly concerned with the length and frequency of streams, geological structures, land use/land cover, climate, relief and slope of the basin. In the study area, the Rc value is 0.29 , indicating that the basin is almost elongated in shape, having low discharge of runoff and highly permeable sub soil conditions (Miller, 1953). This reveals that, there is a higher groundwater potential in the studied basin. The presence of an alluvial aquifer together with alluvial soils in this area evidences for the occurrence of reliable groundwater storage, which is recharged by rains during the Maha Season and by irrigation water supplied from the reservoirs during the dry Yala season (Panabokke, 2007). Cooray (1984) has also stated that one of the largest carriers of groundwater in Sri Lanka is the alluvium which in the major river valleys may vary from 9 to $30 \mathrm{~m}$ in thickness and may extend laterally for hundreds of feet on either side of the river bed.

Horton (1932) introduced the drainage density (Dd) as an important indicator of the linear scale of landform elements in stream eroded topography. The Dd is defined as the ratio of total length of streams of all orders within the basin to the basin area, which is expressed in terms of $\mathrm{km} / \mathrm{km}^{2}$. It indicates the closeness of spacing of channels, thus providing a quantitative measure of the average length of stream channels for the whole basin (Horton, 1932). Dd values may be $1 \mathrm{~km}$ per $\mathrm{km}^{2}$ through very permeable rocks, whereas they increase to over $5 \mathrm{~km}$ per $\mathrm{km}^{2}$ through highly impermeable surfaces. It has been observed from Dd measurements made over a wide range of geologic and climatic types that a low Dd is more likely to occur in regions of highly permeable subsoil material under dense vegetative cover and where relief is low. A high Dd is the resultant of weak or impermeable subsurface material, sparse vegetation and mountainous relief. Low Dd leads to coarse drainage texture while high Dd leads to fine drainage texture (Strahler, 1964).The Dd of the Gal Oya basin is found to be $1.0 \mathrm{~km} / \mathrm{km}^{2}$ indicating a low Dd. As explained by Nag (1998) this has been 
resulted from a permeable land surface with less slope and good vegetation cover prevailing in the basin.

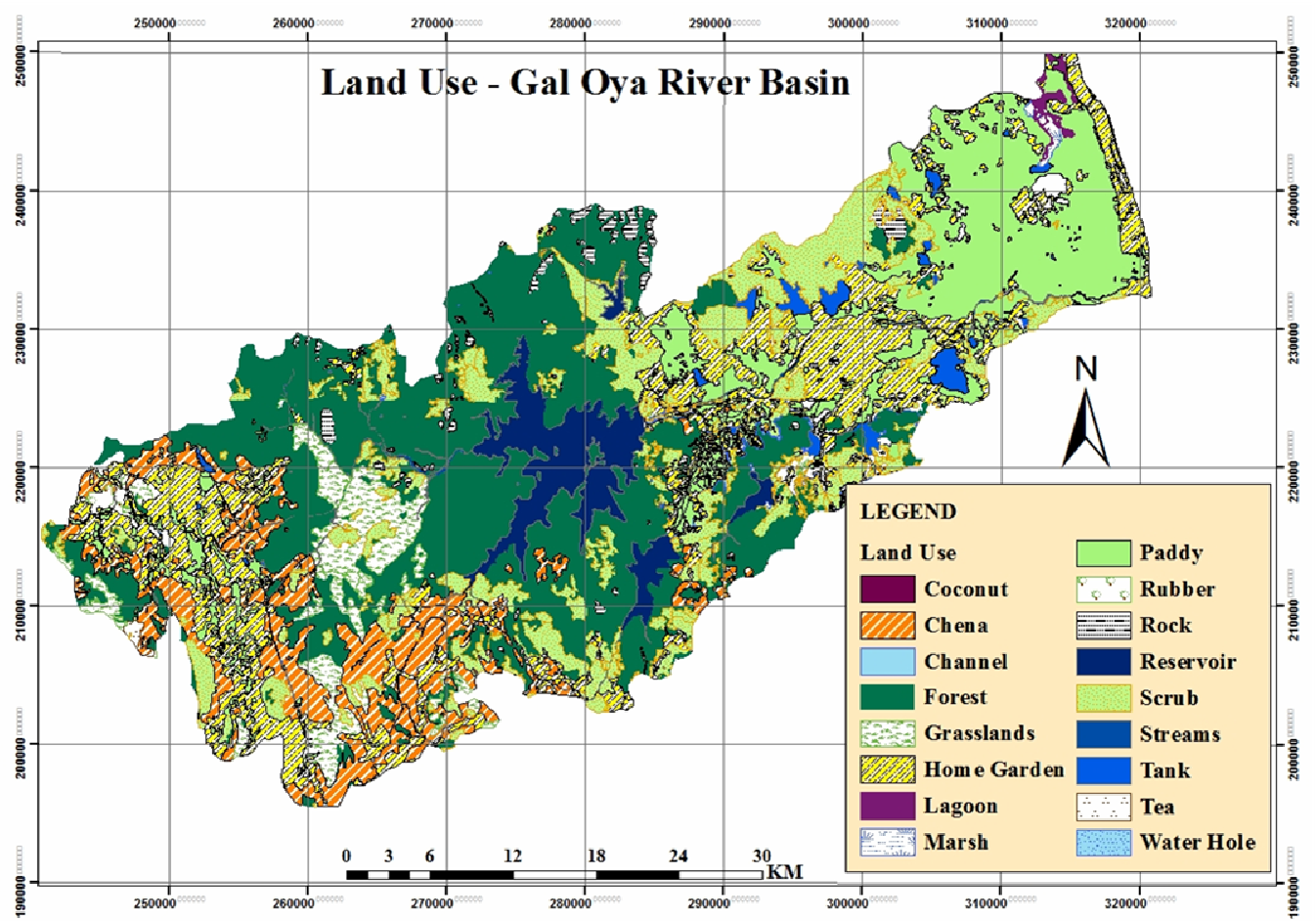

\section{Fig 3. Land use map of Gal Oya river basin}

The results of the land use analysis done for the basin show that the basin has $48 \%$ natural vegetation cover and $24 \%$ cultivated area (Fig. 3) and this provides the evidences for a low Dd value in the basin owing to the occurrence of good vegetation cover.

The $\mathrm{Re}$ is the ratio between the diameter of the circle of the same area as the drainage basin and the maximum length of the basin (Schumm, 1956). It is a very significant index in the analysis of the basin shape which helps to give an idea about the hydrological character of a drainage basin. Strahler (1964) states that this ratio runs between 0.6 and 1.0 over a wide variety of climatic and geologic types. Analysis of elongation ratio has indicated that the areas with higher elongation ratio values have high infiltration capacity and low runoff. A circular basin is more efficient in the discharge of runoff than an elongated basin (Singh and Singh, 1997). The values of elongation ratio generally vary from 0.6 to 1.0 over a wide variety of climate and geologic types. The varying slopes of river basins can be classified with the help of the index of elongation ratio, i.e. circular (0.9-0.10), oval (0.8-0.9), less elongated (0.7-0.8), elongated (0.5-0.7), and more elongated (less than 0.5). The elongation ratio of Gal Oya river basin is 0.59 and it also confirms that the basin is elongated. According to Singh and Singh (1997), this type of basin leads to develop a flatter peak of flow for longer duration.

The Rf may be defined as the ratio of the area of the basin to the square of basin length (Horton, 1932). The values of form factor would always be less than 0.7584 (perfectly for a 
circular basin). It is the quantitative expression of drainage basin outline form. Smaller the value of form factor, more elongated will be the basin. The Rf value of the study area is 0.27 and this also indicates that the basin is elongated in shape. The elongated basin with low $\mathrm{Rf}$ indicates that the basin have a flatter peak with a longer duration. According to Singh and Singh (1997) flood flows of such elongated basins are easier to manage than that from the circular basins.

The $\mathrm{T}$ is one of the important concept of geomorphology which means that the relative spacing of drainage lines. The $\mathrm{T}$ is on the underlying lithology, infiltration capacity and relief aspect of the terrain. The $\mathrm{T}$ is the total number of stream segments of all orders per perimeter of that area (Horton, 1945). The $\mathrm{T}$ depends upon a number of natural factors such as climate, rainfall, vegetation, rock and soil type, infiltration capacity, relief and stage of development (Smith, 1950). Further he explained that the soft or weak rocks unprotected by vegetation produce a fine texture, whereas massive and resistant rocks cause coarse texture. Sparse vegetation of arid climate causes finer textures than those developed on similar rocks in a humid climate. Smith (1950) has classified drainage texture into five different textures i.e., very coarse $(<2)$, coarse ( 2 to 4$)$, moderate ( 4 to 6 ), fine (6 to 8 ) and very fine $(>8)$. In the present study, the drainage texture of the basin is 4.92 and it indicates a moderate drainage texture.

Faniran (1968) defines the Id as the ratio of the stream frequency to the drainage density. This study shows a low drainage intensity of 0.74 for the basin. According to Faniran (1968), this low value of Id implies that Dd and Fs have little effect on the extent to which the surface has been eroded by the agents of soil erosion. Further, the author has explained that as the surface runoff is not quickly removed from the land surface, more water is infiltrated into the soil. The land use map (Fig. 4) of the basin also confirms that the basin is less susceptible for soil erosion as it is well covered with either natural vegetation (48\%) or cultivated crops (24\%). In addition, the gentle slopes of the watershed also reduce the risk of erosion.

Lo refers to the length of the runoff of the rain water on the ground surface before it gets concentrated into definite stream channels and it approximately equals to half of reciprocal of drainage density (Horton, 1945). The length of overland flow of the study area is 0.50 , indicating a low surface runoff in the basin and it further confirms the less susceptibility of the basin for both soil erosion and flooding.

\section{Rainfall records over the basin}

The daily maximum rainfall figures of Bibile gauging station (2001 - 2013) and Padiyatalawa gauging station $(1989$ - 2012) which are located in the upper catchment area of the basin are shown in Fig. 4 and 5. Though it is important to carry out a comprehensive analysis to identify the trends in rainfall with time, the figures show some high rainfall values in recent years which may have attributed to frequent floods in the downstream. 


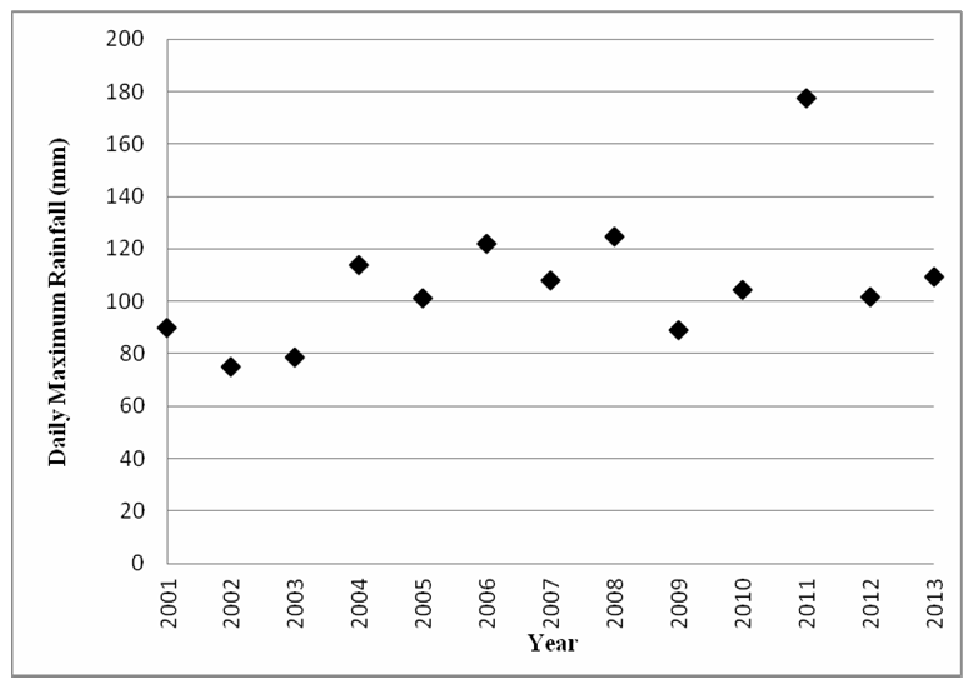

Fig 4. Variation of daily maximum rainfall at Bibile gauging station

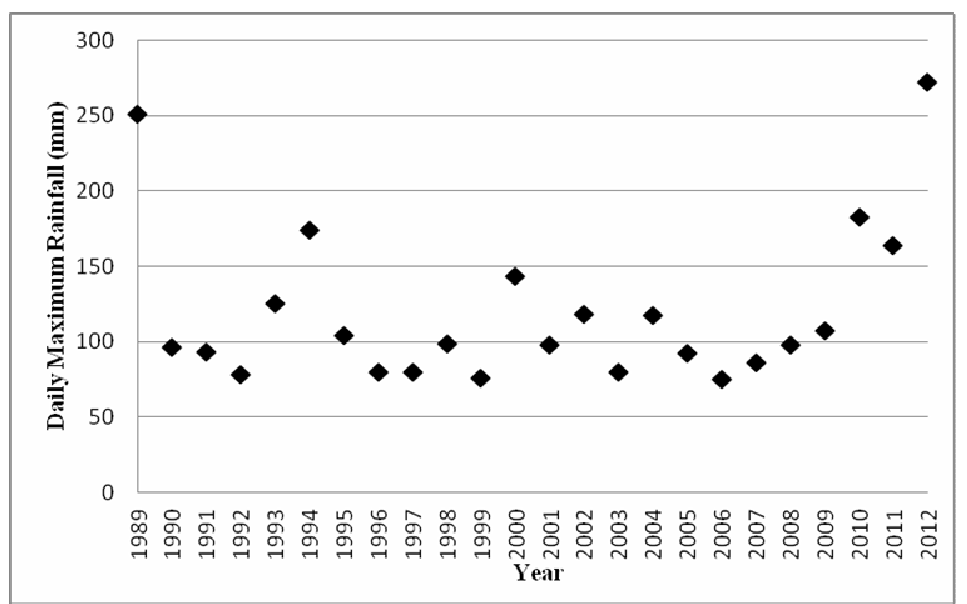

Fig 5. Variation of daily maximum rainfall at Padiyatalawa gauging station

\section{Flood records in Ampara District}

As per the Fig. 6, the number of flood events are relatively high during 2000-2008 period in the downstream areas of the basin (Ampara District) as revealed by the last 30 years flood records obtained from Disaster Management Centre of Sri Lanka (http://www.dmc.gov.lk). 


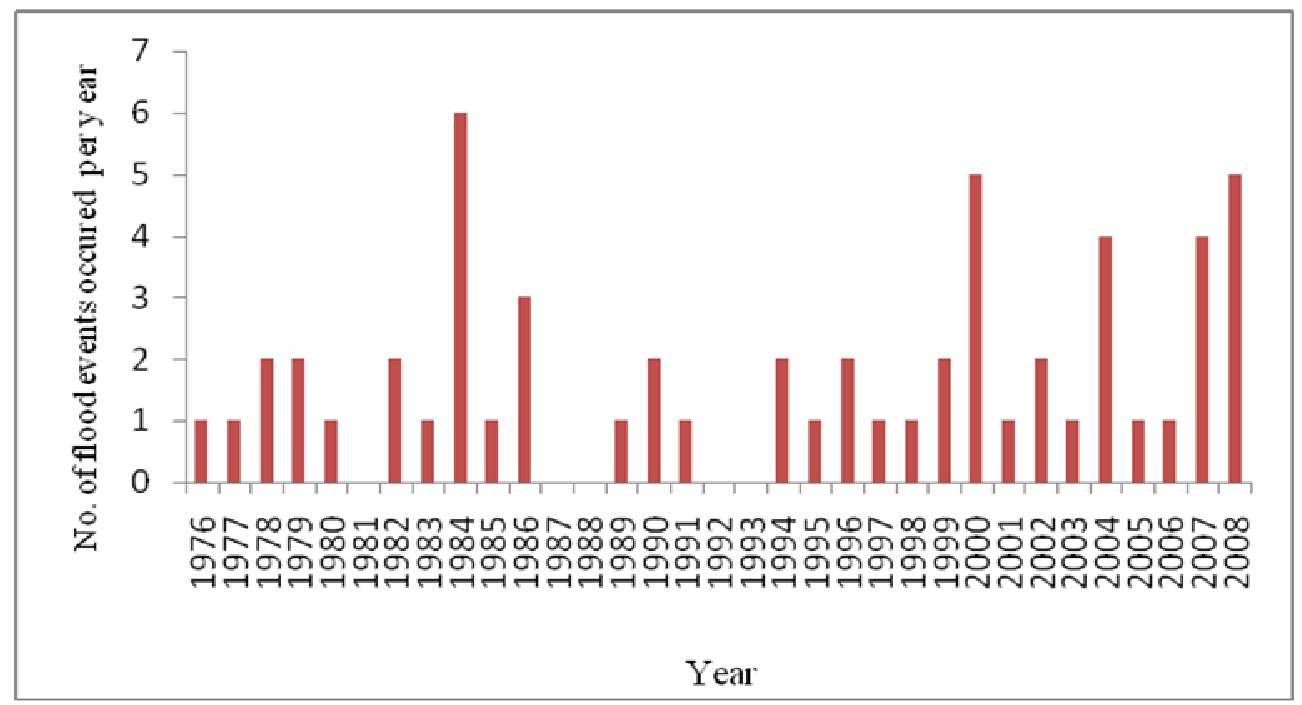

Fig 6. Variation of occurred number of flood events with time in Ampara District

Though, a statistical analysis has not been carried out, the rainfall records at the upper catchment areas of the basin and the flood records of the downstream area of the basin provides an indication that there are changes in the hydrology of the basin which may have partially attributed to the climate change. Though the basin morphology does not support high runoff generation and possible flooding, floods can be generated at anywhere due to the occurrence of high rainfall events and the continuous degradation of natural land use pattern with increasing population and its associated demands.

\section{Relief aspects}

Relief aspects of drainage basin relate to the three dimensional features of the basin involving area, volume and altitude of vertical dimension of landforms wherein different morphometric methods are used to analyze terrain characteristics. The $\mathrm{H}, \mathrm{Rh}$ and $\mathrm{Rhp}$ were studied as the relief aspects of the Gal Oya river basin. Fig. 7 shows the digital elevation model of the Gal Oya river basin.

The $\mathrm{H}$ is defined as the difference in the elevation between the highest point $(\mathrm{Z})$ of a watershed and the lowest point (z) on the valley floor (Strahler, 1957). The elevation at $\mathrm{Z}$ of the Gal Oya river basin is $1341 \mathrm{~m}$ and the $\mathrm{z}$ at the basin mouth is $5 \mathrm{~m}$ from mean sea level. Therefore, the relief of the river basin is $1336 \mathrm{~m}$.

The $\mathrm{Rh}$ can be obtained by dividing the $\mathrm{H}$ from the maximum basin length $(\mathrm{Lb})$ which results in a dimensionless ratio which is equal to the tangent of the angle formed by two planes intersecting at the mouth of the basin (Schumm, 1956). Further, the author has stated that this is a measure of the overall steepness of a river basin and it is an indicator of the intensity of erosion process operating on the slope of the basin. The Rh of the studied basin is 0.02 and it also reveals that the basin is morphometrically less susceptible to severe erosion. 
The Rhp is an important morphometric variable used for the overall assessment of morphological characteristics of terrain. Melton (1957) suggested a method to calculate Rhp by dividing the $\mathrm{H}$ with $\mathrm{P}$. There are three categories of Rhp viz (i) low $=0 \mathrm{~m}-100 \mathrm{~m}$, (ii) moderate $=100 \mathrm{~m}-300 \mathrm{~m}$ and (iii) high $=$ above $300 \mathrm{~m}$. The Rhp of the Gal Oya basin is 0.47 and therefore, the basin has a low relative relief.

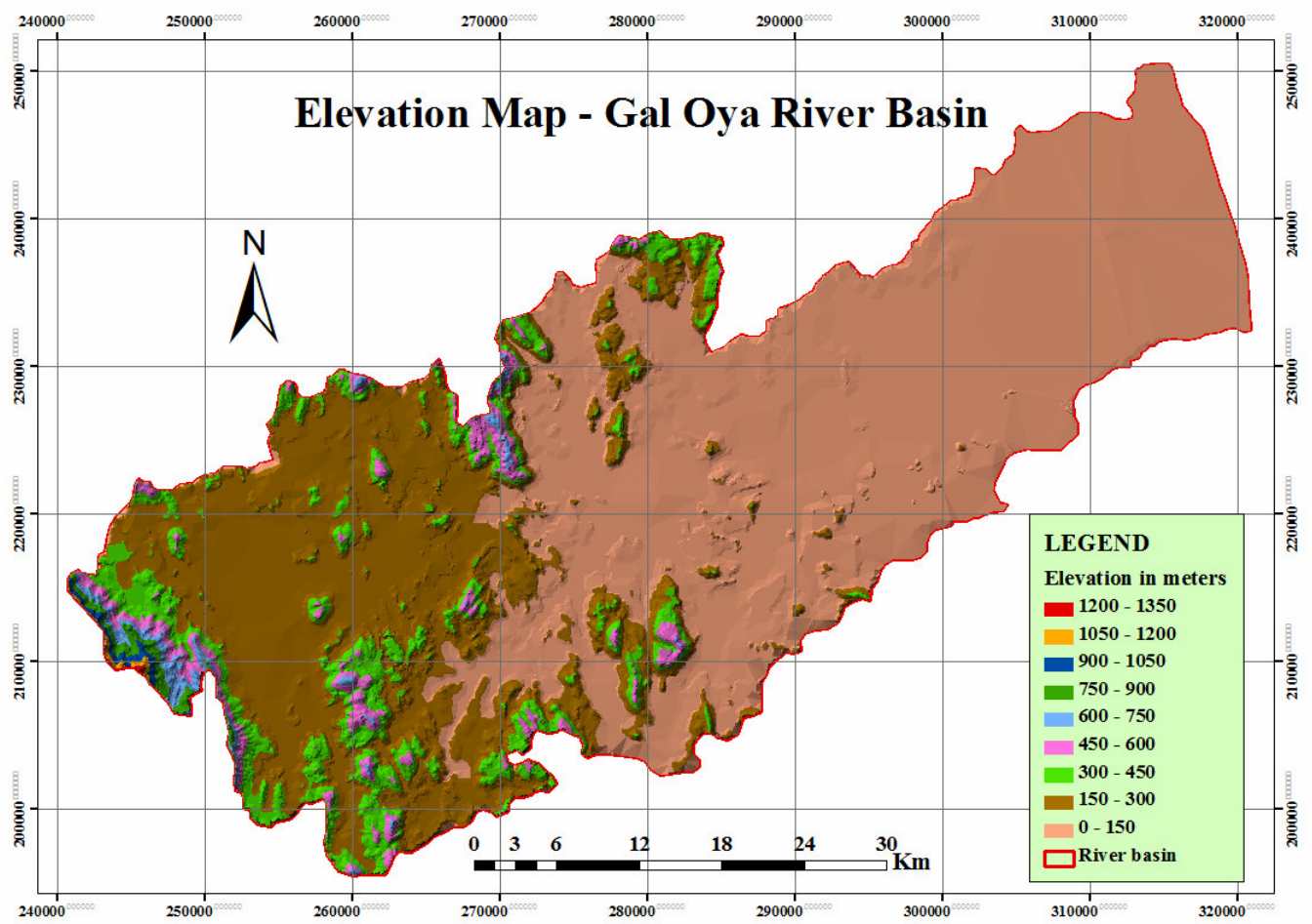

Fig 7. Digital Elevation model of Gal Oya river basin

\section{CONCLUSIONS}

The quantitative morphometric analysis using GIS derived data is a convenient and effective methodology to study the river basin characteristics. The studied Gal Oya river basin has a dendritic drainage pattern with moderate drainage texture showing a $6^{\text {th }}$ order stream network. The high $\mathrm{Rb}$ values reveals that a lower and extended peak flow would result from the basin and it will reduce the risk of flooding. The low Dd value indicates that the basin has highly permeable sub-soil and thick vegetative cover. The low Rc value also indicates that as the basin is almost elongated in shape, it has a low discharge rate of runoff and highly permeable sub soil conditions. The low Re and low Rf values confirm that the basin is elongated and thus the basin has a flatter peak with a longer duration. The lower values of Fs and Id values further confirm that the surface runoff is not quickly removed from the river basin. As the both low Dd and Rc values indicating highly permeable sub soil conditions, accompanied with the high $\mathrm{Rb}$ values and all the low values of Re, Rf, Fs and Id indicating a flatter peak of flow for a longer duration, the basin is well capable of absorbing water into the soil and recharging groundwater while reducing the risk of flooding. If such floods will 
be emerged, those could be managed easily from this type of elongated basins than from circular basins by adopting suitable precautionary measures. Although the studied Gal Oya river basin is inherently and morphomrtrically capable of reducing the flood risk, sustainable management plans should be made in advance to cope with the potential floods that can occur due to high rainfalls which can be resulted from the predicted climate change and ever degrading protective land use/cover due to increasing population together with unstoppable development activities.

\section{REFERENCES}

Chorley, R.J., Donald Malm, E.G. and Pogorzelski, H.A. (1957). A new standard for estimating drainage basin shape, Amer. J. Sci., 255, 138 - 141.

Clarke, J.I. (1966). Morphometry from Maps. Essays in geomorphology. Elsevier Publ. Co., New York, 235 - 274.

Cooray, P.G. (1984). An Introduction to Geology of Sri Lanka (Ceylon), National Museums of Sri Lanka Publication, Colombo.

Faniran, A. (1968). The index of drainage intensity - A provisional new drainage factor, Aus. J. of Sci., 31, $328-330$.

Garde, R.J. (2005). River Morphology, New Age International (Pvt) Ltd. Publishers, New Delhi.

Horton, R.E. (1932). Drainage-basin characteristics. Trans. Am. Geophys. Union, 13, 350 361.

Horton, R.E. (1945). Erosional Development of Streams and Their Drainage Basins, Geolo. Soc. of Am. Bull. 56 (3), 275 - 370.

Kale,V.S. and Guptha, A. (2001). Introduction to Geomorphology, Orient Longman Ltd.

Kanth, T.A. (2012). Morphometric analysis and prioritization of watersheds for soil and water resource management in Wular catchment using Geo-spatial tools", Inter. J. of Geo., Earth and Environ. Sci., 2 (1), 30 - 41.

Madduma Bandara, C.M. (2000). Natural Resources of Sri Lanka 2000, National Science Foundation, 75 - 109.

Melton, M.A. (1957). An Analysis of the relations among elements of climate, Surface properties and geomorphology, Project NR 389042, Tech. Rep. 11, Columbia University.

Miller,V.C. (1953). A quantitative geomorphic study of drainage basin characteristics in the Clinch Mountain area, Varginia and Tennessee, Project NR 389042, Tech. Rept. 3., Columbia University, Department of Geology, ONR, Geography Branch, New York.

Mohd, I., Haroon, S. and Bhat, F.A. (2013). Morphometric Analysis of Shaliganga Sub Catchment, Kashmir Valley, India Using Geographical Information System, International Journal of Engineering Trends and Technology, 4 (1). 
Nag, S.K. (1998). Morphometric analysis using remote sensing techniques in the Chaka subbasin, Purulia district, West Bengal. J. Indian Soc. remote sensing, 26 (1 \& 2), 69 - 76.

Narendra, K. and Nageswara Rao, K. (2006). Morphometry of the Mehadrigedda watershed, Visakhapatnam district, Andhra Pradesh using GIS and Resourcesat data, Jour. Indian Soc. Remote Sensing, 34, 101 - 110.

National Atlas of Sri Lanka, (2007). Survey Department of Sri Lanka.

Panabokke, C.R. (2007). Groundwater Conditions in Sri Lanka: A Geomorphic Perspective, National Science Foundation of Sri Lanka.

Pidwirny, M. (2006). The Drainage Basin Concept. Fundamentals of Physical Geography, $2^{\text {nd }}$ Edition.

Schumm, S.A. (1956). The Evolution of drainage systems and slopes in badlands at Perth Amboi, New Jersey. Geological Society of America Bulletins, 67(5).

Singh, S. and Singh, M.C. (1997). Morphometric analysis of Kanhar river basin. National Geographical Jour. of India 43 (1), 31- 43.

Smith,K.G. (1950). Standards for grading texture of erosional topography, Am. J. Sci., 248, $655-668$.

Strahler, A.N. (1957). Quantitative analysis of watershed geomorphology, Trans. Am. Geophys. Union, 38, 913 - 920.

Strahler, A.N. (1964). Quantitative Geomorphology of drainage basins and channel networks, Handbook of Applied Hydrology, Ed. Ven Te Chow, 04, 9 - 76.

Waugh D. (1996). Geomorphology: An Integrated Approach. Thomson Nelson Publishing Company, London.

http://www.dmc.gov.lk: [Accessed on 14.07.2014] 